九州大学学術情報リポジトリ

Kyushu University Institutional Repository

\title{
Differentiation of Phytopathogenic Pseudomonas and Xanthomonas Pathovars and Strains by PCR Analysis for DNA Topoisomerase Genes
}

\section{Khan, Abu Ashraf}

Laboratory of Plant Pathology, Division of Plant Pathology and Pesticide Science, Department of Applied Genetics and Pest Management, Faculty of agriculture, Kyushu University

Furuya, Naruto

Laboratory of Plant Pathology, Division of Plant Pathology and Pesticide Science, Department of Applied Genetics and Pest Management, Faculty of agriculture, Kyushu University

Matsumoto, Masaru

Institute of Tropical Agriculture, Kyushu University

Matsuyama, Nobuak i

Laboratory of Plant Pathology, Division of Plant Pathology and Pesticide Science, Department of Applied Genetics and Pest Management, Faculty of agriculture, Kyushu University

https://doi.org/10.5109/24350

出版情報: 九州大学大学院農学研究院紀要. 45 (1)，pp.1-6，2000-11. Kyushu University バージョン：

権利関係: 


\title{
Differentiation of Phytopathogenic Pseudomonas and Xanthomonas Pathovars and Strains by PCR Analysis for DNA Topoisomerase Genes
}

\author{
Abu Ashraf Khan, Naruto Furuya, Masaru Matsumoto* \\ and Nobuaki Matsuyama

\begin{abstract}
Laboratory of Plant Pathology, Division of Plant Pathology and Pesticide Science, Department of Applied Genetics and Pest Management, Faculty of Agriculture, Kyushu University, Fukuoka 812-8581, Japan

(Received March 28, 2000 and accepted August 18, 2000)
\end{abstract}

\begin{abstract}
Differentiation of pathovars of Pseudomonas syringae and Xanthomonas campestris was conducted by analysis with polymerase chain reaction (PCR) of topoismerase genes. Differences among the pathovars werc observed on the migration patterns of the PCR products on agarose gel. Banding patterns of respective strains were pathovar specific with some exceptions. The technique is rapid, simple and reproductive to identify and classify phytopathogenic Pseudomonas syringae and Xanthomonas campestris at pathovar level, and it may be a useful diagnostic tool for these important plant pathogens.
\end{abstract}

\section{INTRODUCTION}

The species Pseudomonas syringae and Xanthomonas campestris are subdivided at the infraspecific level into many pathovars. Since pathovars can not be readily distinguished by the ordinary physiological and biochemical methods (Dye, 1962; Palleroni, 1984; Van Zyl and Steyn, 1990), they are classified on the basis of their distinctive pathogenicity to one or more host plants. Unfortunately, identification based on the pathogenicity tests can be inconclusive and open to alternative interpretations (Lazo et al., 1987; Gabriel et al., 1989). Currently, serological tests (Benedict et al., 1989, 1990), fatty acid profiling (Stead, 1992; Vauterin et al., 1992), protein analysis (Van Zyl and Steyn, 1990; Vauterin et al., 1991a, b; Li and Hayward, 1994) and nucleic acid based techniques (Lazo et al., 1987; Alizadeh et al., 1997; Hauben et al., 1997; Manceau and Horvais, 1997) have been used to classify pathovars and strains of Pseudomonas syringae and Xanthomonas campestris. However, these techniques are often time-consuming, too expensive, or too insensitive for use in routine diagnosis. We have used PCR technique to identify rapidly and classify closely related pathogenic bacteria on the basis of genomic fingerprint approaches.

Eubacteria have two indispensable type II DNA topoisomerase, DNA gyrase encoded by gyr $B$ and gyrA and topoisomerase $\mathrm{IV}$ encoded by parE and parC. These genes belong to a single family whose members span both eucaryotes and prokaryotes (Huang, 1996). The type II DNA topoisomerase gene sequences are easily obtainable from diverse sources and the high sequence conservation of this family of the genes throughout the evolution

\footnotetext{
* Institute of Tropicai Agreculture, Kyushu University, Fukuoka 812-8581, Japan
} 
provides a rationale for design of universal primers used in the polymerase chain reaction in order to systematically generate a data set. We demonstrated the utility of the PCR technique with primers corresponding to $g y r B$ gene sequences to generate specific DNA fingerprints and to classify and identify pathovars of phytopathogenic $P$. syringae and $X$. campestris.

\section{MATERIALS AND METHODS}

\section{Bacterial strains}

All the strains used are listed in Table 1. Strains of Pseudomonas syringae and Xanthomonas campestris were grown on King'B (King et al., 1954) and YDC (Wilson, 1967) medium, respectively. Stock cultures were maintained at $4{ }^{\circ} \mathrm{C}$.

\section{PCR-assay}

Bacterial cultures were grown in 523 broth (Kado and Heskett, 1970) for $24 \mathrm{~h}$ at $30^{\circ} \mathrm{C}$. Bacterial cells were harvested in an Eppendorf tube by centrifugation at $5000 \mathrm{rpm}$ for $5 \mathrm{~min}$. About $5 \mathrm{mg}$ bacterial cells was suspended homogeneously in $500 \mu \mathrm{I}$ TE buffers (10 mM Tris- $\mathrm{HCl}, \mathrm{pH} 8.0,1 \mathrm{mM}$ EDTA) and heated at $95^{\circ} \mathrm{C}$ for $8 \mathrm{~min}$. Centrifugation was carried out at $5000 \mathrm{rpm}$ for 30 second and the supernatants were used for PCR.

The PCR primers GYRB-P (5' GTAGGTGTGTCGGTTGTGAA-3') and GYRB-PR (5'-TTTACGGCGGGTCATCTCAC-3') used in this experiment were designed from the conserved regions in the gyrB gene by comparing P. putida (Yamamoto and Harayama, 1995). PCR was carried out in a $100 \mu \mathrm{l}$ reaction mixture containing $68.5 \mu \mathrm{l}$ deionized water, $10 \times$ reaction buffer $(100 \mathrm{mM}$ Tris- $\mathrm{HCl}, \mathrm{pH} 9.0,500 \mathrm{mM} \mathrm{KCl}$ and $1 \%$ Triton $\mathrm{X}-100)$ $10 \mu \mathrm{l}, 25 \mathrm{mM} \mathrm{MgCl}_{2} 10 \mu \mathrm{l}, 5 \mathrm{mM}$ dNTPs $4 \mu \mathrm{l}$, DNA solution $5 \mu \mathrm{l}$, each primer $1 \mu \mathrm{l}$ and Taq DNA polymerase $0.5 \mu \mathrm{l}$, and was overlaid with $50 \mu \mathrm{l}$ of mineral oil. The following PCR programme was used: 1 cycle $94^{\circ} \mathrm{C}$ for $2 \mathrm{~min}, 45^{\circ} \mathrm{C}$ for $3 \mathrm{~min}$ and $72^{\circ} \mathrm{C}$ for $1 \mathrm{~min} ; 30$ cyles $93^{\circ} \mathrm{C}$ for $1 \mathrm{~min}, 42^{\circ} \mathrm{C}$ for $1 \mathrm{~min}$ and $72^{\circ} \mathrm{C}$ for $3 \mathrm{~min}$. Amplified DNA was subjected to electrophoresis in $2 \%$ agarose gel, stained with ethidium bromide, and photographed on a UV transilluminator. Fingerprints generated for different stains were compared visually.

\section{RESULTS AND DISCUSSION}

Primers corresponding to DNA topoisomerase genes generated a specific genomic fingerprint for the strains of Pseudomonas and Xanthomonas. Differences among their pathovars were assessed vissually on the basis of the migration patterns of PCR products on agarose gel electrophoresis. Banding patterns of the strains were pathovar specific in the most cases and homogeneity was observed among the strains within pathovar. Among the strains of $P$. syringae, distinct banding patterns were observed in $P$. syringae pv. tomato, pv. lachrymans, pv. japonica, pv. myricae, pv. oryzae, pv. glycinea, pv. tabaci, pv. theae, pv. coronafaciens, pv. atropurpurea and pv. mori. However, fingerprints generated for $P$. syringae pv. syringae and pv. phaseolicola; $P$. syringae pv. pisi and pv. striafaciens were identical (Figs. 1a, b)

PCR amplified products also generated unique genomic fingerprints for pathovars of $X$. campestris tested. The fingerprint patterns of the representative strains of $X$. 
Table 1. List of Pseudomonas and Xanthomonas pathovars and strains.

\begin{tabular}{|c|c|c|}
\hline Bacterial strain & Isolate & Source \\
\hline \multicolumn{3}{|l|}{ P. syringae } \\
\hline pv. syringae & ATCC $19310^{T}$ & ATCC \\
\hline pv. oryzae & MAFF 301538 & NIAR \\
\hline pv. tabaci & PA-28 & KTES \\
\hline pv. tabaci & $\mathrm{Ku}-7102$ & $\mathrm{AKU}$ \\
\hline pv. lachrymans & NIAS 1319 & NIAS \\
\hline pv. lachrymans & NIAS 1321 & " \\
\hline pv.mori & P-23 & " \\
\hline pv. pisi & MAFF 301211 & NIAR \\
\hline pv. pisi & MAFF 301213 & " \\
\hline pv. theae & MAFF 750001 & " \\
\hline pv. coronafaciens & MAFF 301314 & " \\
\hline pv. phaseolicola & MAFF 301616 & " \\
\hline pv. phaseolicola & MAFF 301716 & " \\
\hline pv.japonica & MAFF 301163 & " \\
\hline pv. atropurpurea & MAFF 301307 & " \\
\hline pv. striafaciens & P-71 & NIAS \\
\hline pv. myricae & MAFF 301464 & NIAR \\
\hline pv. tomato & MAFF 301593 & " \\
\hline pv. glycinea & $\mathrm{KN}-28$ & NIAS \\
\hline \multicolumn{3}{|l|}{$X$ campestris } \\
\hline pv. citri & $12-5$ & AKU \\
\hline pv. citri & $32-5$ & " \\
\hline pv. citri & $\mathrm{Ku}-7501$ & " \\
\hline pv. citri & C 1 & " \\
\hline pv. citri & $\mathrm{C} 2$ & " \\
\hline pv. campestris & ATCC $33913^{\mathrm{T}}$ & ATCC \\
\hline pv. campestris & I & TUA \\
\hline pv. hyacinthi & $X 1-4-1$ & NIAS \\
\hline pv. translucens & $\times 1-11-2$ & $"$ \\
\hline pv. glycines & S-9 & AKU \\
\hline pv. glycines & S-10 & " \\
\hline pv. vitians & I & NIAS \\
\hline pv. vitians & II & " \\
\hline pv. pisi & 1 & " \\
\hline pv. pisi & II & " \\
\hline pv. pisi & III & " \\
\hline pv. physalidicola & 2 & " \\
\hline pv. phaseoli & $318-1$ & $"$ \\
\hline
\end{tabular}

ATCC: American Type Culture Collection, USA.

NIAR: National Institute of Agrobiological Resources, Tsukuba, Japan.

KTES: Kagoshima Tobacco Experiment Station, Japan.

AKU: Faculty of Agriculture, Kyushu University, Fukuoka, Japan

TUA: Tokyo University of Agriculture, Tokyo, Japan.

NIAS: National Institute of Agricultural Sciences, Tokyo, Japan.

KNAES: Kyushu National Agricultural Experiment Station, Kumamoto, Japan.

Type culture: Small $\mathrm{T}$ at the shoulder of isolate number indicates type culture. 




Fig. 1a. Electrophoretic patterns of PCR-amplified topoisomerase genes of $P$. syringae pathovars and strains.

M: Molecular marker (100-bp ladder); 1: P. syr. pv. syringae ATCC 19310 ; 2: pv. tomato MAFF 301593; 3: pv. phaseolicola MAFF 301716; 4: pv. phaseolicola MAFF 301616; 5: pv. pisi MAFF 301211; 6: pv. pisi MAFF 301213; 7: pv. tabaci PA-28; 8: pv. tabaci Ku-7102; 9: pv. lachrymans NIAS 1319; 10: pv. lachrymans NIAS 1321.



Fig. 1b. Electrophoretic patterns of PCR-amplified topoisomerase genes of $P$. syringae pathovars and strains.

M: Molecular marker (100-bp ladder); 1: pv. tomato MAFF 301593; 2: pv. phaseolicola MAFF 301716; 3: pv. pisi MAFF 301211; 4: pv. tabaci PA-28; 5: pv. lachrymans NIAS 1319; 6: pv. straifaciens P 71; 7: pv. oryzae MAFF 301538; 8: pv. glycinea KN-28; 9: pv. mori P-23; 10: pv. japonica MAFF 301163; 11: pv. coronafaciens MAFF 301314; 12: pv. atropurpurea MAFF 301307; 13: pv. myricae MAFF 301464; 14: pv. theae MAFF 750001. 


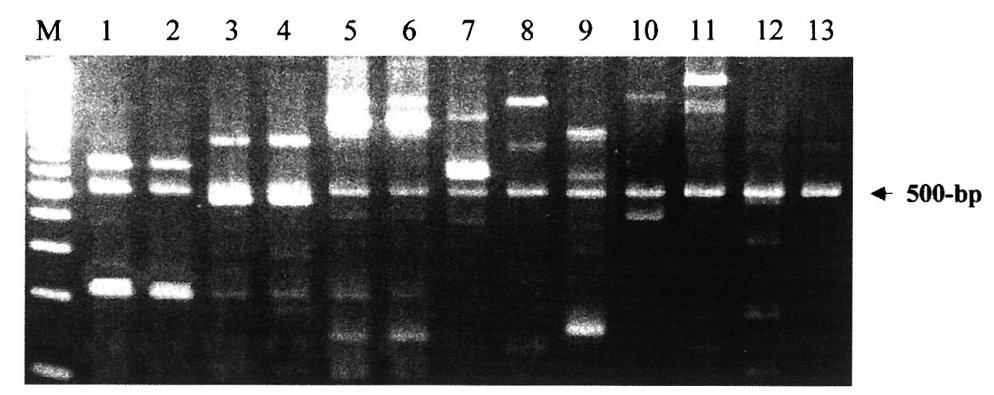

Fig. 2. Electrophoretic patterns of PCR-amplified topoisomerase genes of Xanthomonas pathovars and strains.

Lanes M: Molecular marker (100-bp ladder), 1: X. campestris pv. citri 32-5, 2: pv. citri Ku 7501, 3: pv. pisi II, 4: pv. pisi III, 5: pv. vitians I, 6: pv. vitians II, 7: pv. hyacinthi $\mathrm{X}-1-4-1,8$ : pv. physalidicola 2, 9: pv. pruni 1-10-1, 10: pv. phaseoli 318-1, 11: pv. translucens X-1-11-2, 12: pv. campestris I, 13: pv. glycines $\mathrm{S}-10$.

campestris pv. citri, pv. pisi, pv. vitians,. pv. hyacinthi, pv. physalidicola, pv. pruni, pv. phaseoli, pv. translucens, pv. campestris and pv. glycines are shown in Fig. 2. Five strains of $X . c$. pv. citri, three strains of $X . c$. pv. pisi and two strains of X.c. pv. vitians showed homogenous patterns within the respective pathovars. Specific banding patterns were also observed for one strain of each X. c. pv. hyacinthi, pv. physalidicola, pv. pruni, pv. phaseoli and pv. translucens. However, those of strains of X.c. pv. campestris and X.c. pv. glycines were identical and not distinguishable each other (Fig. 2 ). The experiment was repeated 2 to 3 times and reproductive results for fingerprint profiles were obtained.

The data presented here suggest that the technique is useful to identify $P$. syringae and $X$. campestris at pathovar level, and this method will provide a rapid and precise way to identify closely related plant pathogenic bacteria.

\section{REFERENCES}

Alizadeh, A., M. Arlat, A. Sarrafi, C. A. Boucher and G. Barrault 1997 Restriction fragment length polymorphism analyses of Iranian strains of Xanthomonas campestris from cereals and grasses. Plant Dis., 81: 31-35.

Benedict, A. A., A. M. Alvarez, J. Berestecky, W. Imanaka, C. Y. Mizumoto, L. W. Pollard, T. W. Mew and C. F. Gonzalez 1989 Pathovar specific monoclonal antibodies for Xanthomonas campestris pv. oryzae and for Xanthomonas campestris pv. oryzicola. Phytopathology, 79: 322-328.

Benedict, A. A., A. M. Alvarez and L. W. Pollard 1990 Pathovar specific antigens for Xanthomonas campestris pv. begoniae and Xanthomonas campestris pv. pelargonii detected with monoclonal antibodies. Appl. Environ. Microbiol., 56: 572-574.

Dye, D. W. 1962 The inadequacy of the usual determinative tests for the identification of Xanthomonas spp. N. Z. J. Sci., 5: 393-416.

Gabriel, D. W., M. T. Kingsley, G. E. Hunter and T. Gottwald 1989 Reinstatement of Xanthomonas citri 
(ex Hasse) and $X$. phaseoli (ex Smith) to species and reclassification of all $X$. campestris pv. citri strains. Int. J. Syst. Bacteriol., 39: 14-22.

Hauben, L., L. Vauterin, J. Swings and E. R. B. Moore 1997 Comparison of 16 S ribosomal DNA sequences of all Xanthomonas species. Int. J. Syst. Bacteriol., 47, 328-335.

Huang, W. M. 1996 Bacterial diversity based on type II DNA topoisomerase genes. Ann. Rev. Gen. 30: 79-107.

Kado, C. I. and M. G. Heskett 1970 Selective media for isolation of Agrobacterium, Corynebacterium, Erwinia, Pseudomonas, and Xanthomonas. Phytopathology, 60: 969-976.

King, E. O., M. K. Ward and D. E. Raney 1954 Two simple media for the demonstration of pyocyanin and fluorescein. J. Lab. Clin. Med., 44: 301-307.

Lazo, G. R., R. Roffey and D. W. Gabriel 1987 Pathovars of Xanthomonas campestris are distinguishable by restriction fragment length polymorphism. Int. J. Syst. Bacteriol., 37: 214 -221.

Li, X. and A. C. Hayward 1994 Bacterial whole cell protein profiles of the rRNA group II pseudomonads. J. Appl. Bacteriol., 77: 308-318.

Manceau, C. and A. Horvias 1997 Assessment of genetic diversity among strains of Pseudomonas syringae by PCR-restriction fragment length polymorphism analysis of rRNA operons with special emphasis on P. syringae pv. tomato. Appl. Environ. Microbiol., 63: 498-505.

Palleroni, N. J. 1984 Genus I Pseudomonas Mingula 1894. In Bergcy's Manual of Systematic Bacteriology. Vol. 1. Baltimore: Williams \& Wilkins. pp.141-199.

Stead, D. E. 1992 Grouping of plant-pathogenic and some other Pseudomonas spp. by using cellular fatty acid profiles. Int. J. Syst. Bacteriol., 42: 281-295.

Van Zyl, E. and P. L. Steyn 1990 Differentiation of phytopathogenic Pseudomonas and Xanthomonas species and pathovars by numerical taxonomy and protein gel electrophoregrams. Syst. Appl. Microbiol., 13: 60-71.

Vauterin, L., J. Swings and K. Kersters 1991a Grouping of Xanthomonas campestris pathovars by SDS-PASE of proteins. J. Gen. Microbiol., 137: 1677-1687.

Vauterin, L., P. Yang, B. Hoste, M. Vancanneyt, E. L. Civerolo, J. Swings and K. Kersters $1991 \mathrm{~b}$ Differentiation of Xanthomonas campestris pv. citri strains by sodium dodecyl sulphatepolyacrylamide gel electrophoresis of proteins, fatty acid analysis, and DNA-DNA hybridization. Int. $J$. Syst. Bacteriol., 41: 535-542.

Vauterin, L., P. Yang, B. Hoste, B. Pot, J. Swings and K. Kersters 1992 Taxonomy of xanthomonads from cereals and grasses based on SDS-PAGE of proteins, fatty acid analysis, and DNA-DNA hybridization. J. Gen. Microbiol., 138: 1467-1477.

Wilson, E. E., F. M. Zeitoun and D. L. Fredrickson 1967 Bacterial phloem canker, a new disease of Persian walnut trees. Phytopathology, 57:618-621

Yamamoto, S. and S. Harayama 1995 PCR amplification and direct sequencing of gyrB genes with universal primers and their application to the detection and taxonomic analysis of Pseudomonas putida strains. Appl. Environ. Microbiol., 61: 1104-1109. 